\title{
Heparin Clearance in the Newborn
}

\author{
MARILYN M. MCDONALD, LINDA J. JACOBSON, WILLIAM W. HAY, JR., AND \\ WILLIAM E. HATHAWAY ${ }^{(28)}$ \\ University of Colorado Health Sciences Center, Denver, Colorado, USA
}

\begin{abstract}
Summary
Twenty-five preterm newborns were given bolus infusions of sodium heparin (100 units/ $\mathrm{kg}$ ) and plasma heparin levels were assayed at $5,20,40,90$, and $150 \mathrm{~min}$. Eight normal adults received a 75 units/ $\mathrm{kg}$ bolus of heparin and levels were assayed at 5, 30, 60, 120,180 , and $240 \mathrm{~min}$. In comparison with the adult data (mean adult plasma heparin half life $(T 1 / 2)=63.3 \mathrm{~min})$, the newborn infants demonstrated a significantly shorter plasma heparin half life $\left(T^{1 / 2}=35.5 \mathrm{~min}\right.$ in group $I, 33$ to 36 wk gestation; $35.5 \mathrm{~min}$ in group II, 29 to 32 wk gestation; and $41.6 \mathrm{~min}$ in group III, 25 to 28 wk gestation), as demonstrated by a chromogenic heparin assay. The newborn groups had a larger volume of distribution $\left(V_{d}\right)$ of heparin which varied inversely with gestational age $\left(V_{d}=36.6 \mathrm{ml} /\right.$ $\mathrm{kg}$ in the adults, $57.8 \mathrm{ml} / \mathrm{kg}$ in group $\mathrm{I}, 73.3 \mathrm{ml} / \mathrm{kg}$ in group $\mathrm{II}$, and $81.0 \mathrm{ml} / \mathrm{kg}$ in group III babies. Heparin clearance (Cl) was significantly greater in all newborn groups when compared with the adult $\left(\mathrm{Cl}_{\mathrm{Adult}}=0.43 \mathrm{ml} / \mathrm{kg} / \mathrm{min} ; \mathrm{Cl}_{\mathrm{GrI}}=1.37 \mathrm{ml} / \mathrm{kg} / \mathrm{min} ; \mathrm{Cl}_{\mathrm{Gr} \text { II }}\right.$ $=1.43 \mathrm{ml} / \mathrm{kg} / \mathrm{min} ;$ and $\left.\mathrm{Cl}_{\mathrm{Gr} \text { III }}=1.49 \mathrm{ml} / \mathrm{kg} / \mathrm{min}\right)$. A one-stage clotting assay for heparin generated similar results, although infant plasma heparin levels were slightly higher by this assay. Before heparin administration, the mean antithrombin III antigen (AT-III Ag) of the babies was $26.5 \%$ of normal adult and was not further decreased $90 \mathrm{~min}$ after the heparin bolus.
\end{abstract}

\section{Speculation}

The larger volume of distribution of heparin could require a greater loading dose per $\mathrm{kg}$ body weight to achieve a desired plasma level and the more rapid plasma clearance could necessitate higher infusion rates to maintain a desired plasma heparin level in newborn infants. The authors speculate that the study findings are the additive result of the more rapid metabolic rate of the newborn and the physiologically low circulating levels of antithrombin III.

Although thrombotic episodes in the newborn are frequently recognized $(2,5,18,19,20,26)$, therapeutic heparinization is often difficult to achieve (27), and published results have indicated both increased (10) and decreased (16) sensitivity to heparin. To date, scant data are available regarding heparin metabolism or plasma clearance for the neonate (21). Heparin kinetics after a single intravenous bolus dose have been studied in adults utilizing prolongation of clotting parameters $(9,17)$ and, more recently, measurements of plasma heparin levels (23). To provide the basis for estimations of heparin dosage, the present study was performed comparing plasma heparin disappearance in newborns with that in adults after a single bolus heparin infusion.

\section{MATERIALS AND METHODS}

The heparin preparation utilized was porcine intestinal sodium heparin, 1000 units/ml (Panheparin, Abbott Laboratories), and all study heparin was of one lot, no. 86-196-AF.

Heparin assays and AT-III Ag were performed on plasma procured by the two-syringe technique. For adults, one volume of
$0.1 \mathrm{M}$ buffered citrate anticoagulant to nine volumes of whole blood was used. In all newborns a central arterial hematocrit was first performed, and the volume of anticoagulant was appropriately adjusted (11). The newborn samples were obtained through indwelling umbilical arterial catheters from which $3 \mathrm{ml}$ of blood had been withdrawn to remove any infusion fluid in the line. All samples were immediately placed on ice and centrifuged at 2000 $\times g$ for $20 \mathrm{~min}$ at $4^{\circ} \mathrm{C}$. Previous experiments in this laboratory indicated that plasma obtained by this method did not contain increased levels of platelet factor 4

All injections of heparin were given in sites other than those used for subsequent sampling. No fluids containing heparin were given to the infants during the study period.

Standard normal plasma (SNP) was pooled from 30 healthy and fasting male and female volunteers. All samples were immediately centrifuged twice at $4^{\circ} \mathrm{C}$ and stored at $-70^{\circ} \mathrm{C}$.

Heparin was assayed in duplicate on all samples with two methods. First, the one-stage clotting assay was adapted from that described by Chen et al. (6). Cephalin was prepared from rabbit brain (Bactothromboplastin; Difco Laboratories, Detroit, MI) according to the methodology of Bell and Alton (4). Activated factor $\mathrm{X}$ (Xa; Sigma Chemical Company, St. Louis, MO) was reconstituted in a Tris buffer [Trizal; Sigma Chemical Company; pH 8.4, containing bovine serum albumin $(10 \mathrm{mg} / \mathrm{ml})]$. In performance of the assay, $0.05 \mathrm{ml}$ of test plasma, $0.15 \mathrm{ml} \mathrm{SNP}, 0.1 \mathrm{ml}$ cephalin, and $0.05 \mathrm{ml}$ of $\mathrm{Xa}$ were added to a prewarmed fibrometer cup. After a 2 -min incubation at $37^{\circ} \mathrm{C}, 0.05 \mathrm{ml}$ of $0.05 \mathrm{M} \mathrm{CaCl}_{2}$ was added, and the clotting time was recorded.

A second chromogenic assay of heparin was performed as described by Teien et al. (25) utilizing cleavage of a synthetic peptide substrate, S-2222 (Kabi Diagnostica, Stockholm, Sweden) by Xa (Sigma Chemical Co.) reconstituted to 8 units $/ \mathrm{ml}$ with the buffer described above. In performance of the test, $0.02 \mathrm{ml}$ of test plasma is diluted with $0.02 \mathrm{ml} \mathrm{SNP}$ and $0.16 \mathrm{ml}$ of a $0.05 \mathrm{M}$ Tris, $0.0075 \mathrm{M} \mathrm{Na}_{2}$ EDTA. $2 \mathrm{H}_{2} \mathrm{O}$ buffer, $\mathrm{pH} 8.4$, containing $0.175 \mathrm{M}$ $\mathrm{NaCl}$. After a $3-\mathrm{min}$ warming at $37^{\circ} \mathrm{C}, 0.1 \mathrm{ml} \mathrm{Xa}$ is added for an incubation of 30 seconds $(0.1$ to $0.8 \mathrm{unit} / \mathrm{ml}$ heparin) or $180 \mathrm{sec}$ (0.02 to 0.2 unit $/ \mathrm{ml}$ heparin). S-2222 $(0.2 \mathrm{ml}, 1 \mathrm{mmole} / \mathrm{liter})$ is added for a 3 -min incubation at $37^{\circ} \mathrm{C}$ and the reaction then stopped with $0.3 \mathrm{ml} 50 \%$ acetic acid. Absorbance of test samples was read in a Gilford $300-\mathrm{N}$ spectrophotometer at $405 \mathrm{~nm}$ against a blank which was also prepared with test plasma.

A standard normal curve was prepared with SNP for both heparin assays with the addition of known amounts of Panheparin. AT-III Ag was measured by the immunologic method of Laurell (13) using a rabbit antihuman AT-III antibody (Behring Diagnostics, Somerville, NJ). The values obtained were expressed as percentage of SNP.

Twenty-five newborns between 25 and 36 wk gestation were each given a single intravenous bolus of heparin (100 units $/ \mathrm{kg}$ ) within $4 \mathrm{hr}$ of birth. The newborns were first judged to be stable by clinical evaluation of the attending neonatologist and the investigator. Gestational age was assessed by the newborn maturity rating and classification scale of Ballard et al. (1) administered by the house officer and by examination of the attending neonatologist. Adequate ventilation was first established in all babies. 
Systolic blood pressures were normal for birth weight as published by Kitterman et al. (12) and perfusion was adequate by capillary filling. Written informed consent was obtained from the mother in each case. Babies not fulfilling these criteria were excluded from the study. The babies were divided into groups according to gestational age where group I = babies 33 to 36 wk gestation, group $\mathrm{II}=29$ to $32 \mathrm{wk}$ gestation, and group III $=25$ to $28 \mathrm{wk}$ gestation. The babies ranged in size from 3210 to $680 \mathrm{~g}$. There were three small-for-gestational-age infants, two twins, seven babies with transient tachypnea, 17 with hyaline membrane disease, and one baby with pneumonia. There were two infants of diabetic mothers. This study was approved by the Human Subjects Committee of the University of Colorado Health Sciences Center.

Eight healthy adults each received sodium heparin (75 units/ $\mathrm{kg}$ ) as a single intravenous injection. This dose was calculated to adjust for the smaller plasma volume in adults to achieve a comparable initial plasma drug level. One additional adult received a 75 units $/ \mathrm{kg}$ infusion to determine the relative contributions of distribution and elimination to the plasma disappearance curves with frequent sampling.

Blood samples were obtained from all babies at 5, 20, 40, 90, and in nine babies at $150 \mathrm{~min}$. Adult samples were drawn at 5, 30, $60,120,180$, and $240 \mathrm{~min}$. This schedule of adult sampling was established after initial studies revealed the longer plasma disappearance time in an attempt to follow 2.5 half-lives. In the additional adult study, blood was sampled every 3 min during the initial $15 \mathrm{~min}$ and then at frequent intervals as shown in Figure 1. Samples were drawn for three of nine adult studies through indwelling venous catheters. Results of these studies did not differ from the six performed with serial venipuncture.

AT-III Ag was measured on a preheparin plasma sample in all subjects and was repeated on the $90 \mathrm{~min}$ sample in the newborns.

\section{ANALYSIS}

A single compartment system with first-order kinetics was assumed for the heparin used in this study. This system is described (14) by the equation

$$
\mathrm{C}_{\mathrm{p}}=\mathrm{C}_{\mathrm{p}_{0}} \mathrm{e}^{-\mathrm{kt}}
$$

where $C_{p}=$ the plasma concentration, $C_{p_{0}}=$ the initial plasma concentration, $\mathrm{e}=$ the base of the natural logarithm, $\mathrm{k}=$ the elimination constant, and $t=$ time.

A curve was plotted for each subject study, and a least squares regression analysis was performed. The plasma half-life $\left(\mathrm{T}^{1} 1 / 2\right)$ and $\mathbf{k}$ were determined from each curve.

Standard formulae (14) were used to compute the $\mathrm{V}_{\mathrm{d}}$ and $\mathrm{Cl}$ for

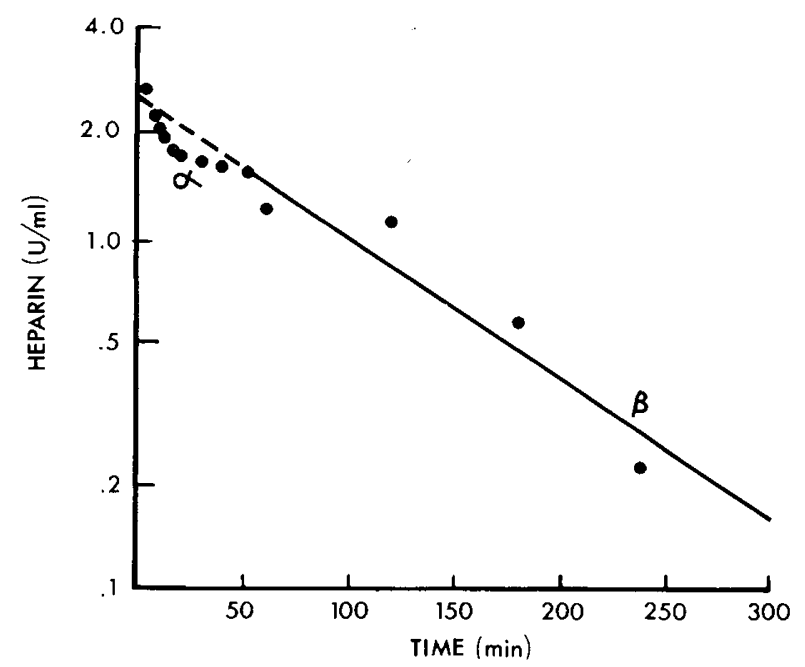

Fig. 1. Contributions of distribution $(\alpha)$ and elimination $(\beta)$ to plasma heparin disappearance in a normal adult. each study where

$$
\begin{aligned}
& \mathrm{V}_{\mathrm{d}}=\frac{\text { dose }}{\mathrm{C}_{\mathrm{p}_{0}}} \\
& \mathrm{Cl}=\mathrm{V}_{\mathrm{d}} \mathrm{xk}
\end{aligned}
$$

The correlation of each curve with first order kinetics was 0.94 or greater. The results of each group of newborns were compared with the adult data utilizing the Student $t$ test.

\section{RESULTS}

In the group of normal adults, the mean $\mathrm{T}^{1} / 2$ was $63.3 \mathrm{~min}$ with a $V_{d}=36.6 \mathrm{ml} / \mathrm{kg}$ and a clearance of $0.43 \mathrm{ml} / \mathrm{kg} / \mathrm{min}$ as determined by the chromogenic assay (Table 1).

In contrast to these data, all three groups of newborns showed significantly shorter half-lives with the mean $\mathrm{T}^{1 / 2}$ of group $\mathrm{I}=35.5$ min, group II $=35.5 \mathrm{~min}$, and group III $=41.6 \mathrm{~min}$. The $\mathrm{V}_{\mathrm{d}}$ in the newborns was inversely proportional to gestational age. The elimination constant in all groups of newborns was significantly larger than the adult $\mathrm{k}$ yielding clearance rates greater than three times adult in all newborn groups.

Data generated by the one-stage clotting assay showed similar results although differences were less marked (Table 2). Results of the two heparin assays performed on each normal adult sample showed an acceptable intertest correlation coefficient (0.92).

The AT-III Ag of all adults fell within the normal range of 83 to $117 \%$ in this laboratory (mean, 102). The mean AT-III Ag of the preheparin infant samples was $26.5 \%$ (range, 17 to $34 \%$ ) and did not vary significantly among the groups. At 90 min postheparin bolus, the AT-III Ag in the newborns was unchanged (Table 3).

\section{DISCUSSION}

Although newborns have significant decreases in both circulating procoagulants and anticoagulants (3), whole blood clotting is accelerated on thromboelastogram (2), and clinical thromboses do occur $(2,5,18,19,20,26)$.

Little data are available to guide the administration of heparin in the neonatal period. Markarian et al. (16) suggested that sick preterm infants have a "resistance" to heparin therapy, whereas others (10) indicated that the newborn infant may be more sensitive to heparin. Rogner (21) followed the heparin-induced prologation of the partial thromboplastin time in preterm and hypoxic term babies given bolus doses of heparin (50 and 100 units $/ \mathrm{kg}$ ) and found the anticoagulant effect to be shorter than that in adults. Boluses of these dosages on a 3 hourly schedule produced variable periods of inadequate anticoagulation between injections. More even anticoagulation was demonstrated using one-half the total units of heparin with a continuous infusion.

This study was conducted to study the plasma clearance of heparin administered by single bolus injection in stable preterm babies. Although clotting studies were not performed on the subject infants, previous detailed clotting assays on a comparable group of preterm infants (3) showed coagulation screening test values which were only slightly different from older prermature and term infants. The obvious limitations to blood sampling in newborns precluded the study of multiple doses or sequential boluses. Because of the risks associated with umbilical arterial catheterizations, normal term infants were not included in the study. We selected newborns with indwelling arterial lines for sampling; all babies studied had some form of respiratory distress and required supplemental oxygen to normalize their $\mathrm{PaO}_{2}$. The stability and relative health of these babies did not justify the use of continuous heparin for study. The single bolus of 100 units $/ \mathrm{kg}$ was therefore chosen as a standard therapeutic dose and the sampling selected to follow 2.5 half-lives.

The plasma heparin disappearance, using a single dose and with sampling at the times noted, yielded results conforming to first- 
Table 1. Pharmacokinetic calculations of bolus heparin infusions using the chromogenic heparin assay

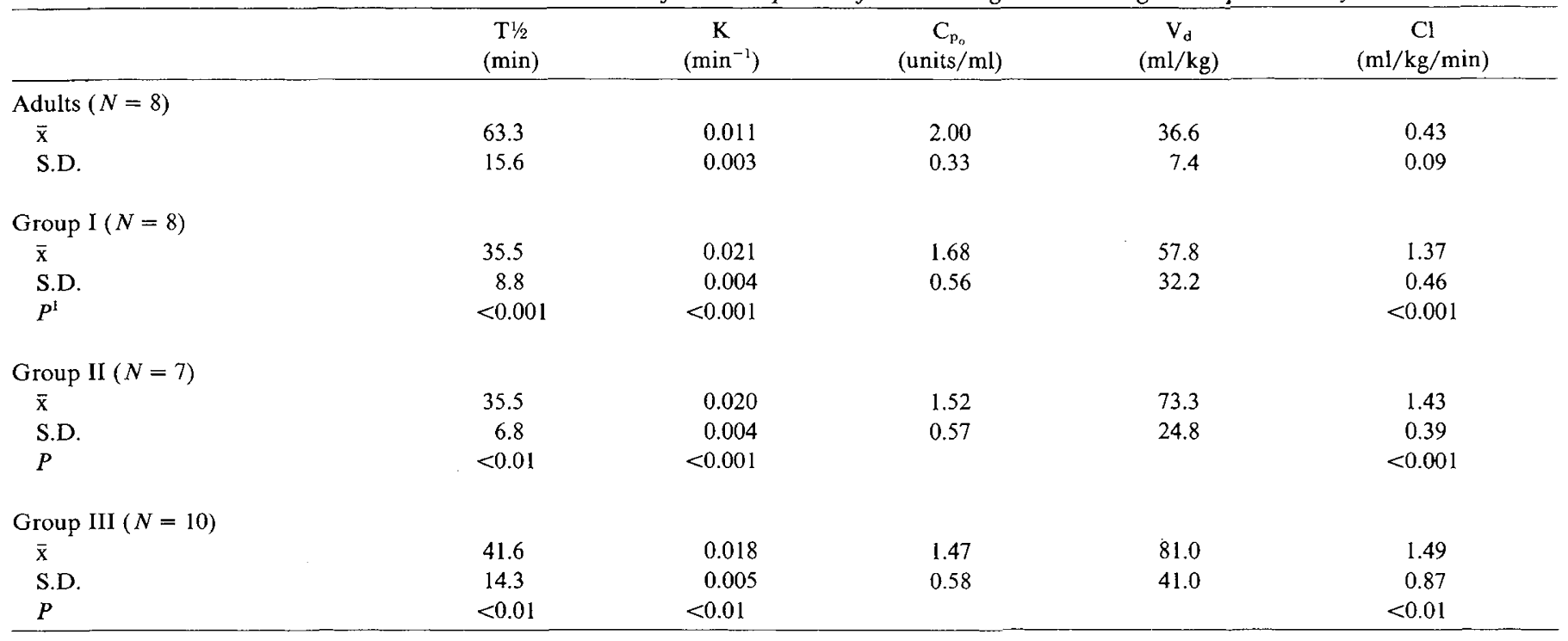

${ }^{1}$ The $P$ values relate the respective infant group to the adult.

Table 2. Pharmacokinetic calculations of bolus heparin infusions using the one-stage heparin assay

\begin{tabular}{|c|c|c|c|c|c|}
\hline & $\begin{array}{c}\mathrm{T}^{1} / 2 \\
(\mathrm{~min})\end{array}$ & $\begin{array}{c}\mathrm{K} \\
\left(\mathrm{min}^{-1}\right)\end{array}$ & $\begin{array}{c}\mathrm{C}_{\mathrm{p}_{\mathrm{o}}} \\
\text { (units/ml) }\end{array}$ & $\begin{array}{c}V_{d} \\
(\mathrm{ml} / \mathrm{kg})\end{array}$ & $\begin{array}{c}\mathrm{Cl} \\
(\mathrm{ml} / \mathrm{kg} / \mathrm{min})\end{array}$ \\
\hline \multicolumn{6}{|c|}{ Adults $(N=8)$} \\
\hline$\overline{\mathrm{x}}$ & 61.5 & 0.011 & 2.14 & 35.6 & 0.40 \\
\hline \multicolumn{6}{|c|}{ Group I $(N=8)$} \\
\hline$\overline{\mathrm{x}}$ & 42.6 & 0.018 & 1.68 & 56.4 & 0.98 \\
\hline \multicolumn{6}{|c|}{ Group II $(N=7)$} \\
\hline$\overline{\mathrm{x}}$ & 48.3 & 0.016 & 1.60 & 67.4 & 1.10 \\
\hline S.D. & 18.8 & 0.005 & 0.47 & 19.1 & 0.50 \\
\hline$P$ & 0.1 & $<0.05$ & & & $<0.01$ \\
\hline
\end{tabular}

${ }^{1}$ The $P$ values relate the respective infant group to the adult.

order kinetics (Fig. 2). In this study, when heparin levels were sampled every $3 \mathrm{~min}$ during the first $15 \mathrm{~min}$ in one adult, a very brief distribution phase was documented (Fig. 1). Therefore, the values obtained on study subjects are considered to closely approximate the elimination phase of plasma heparin disappearance.

The plasma heparin $\mathrm{T}^{1} / 2$ in newborns was longer (group $\mathrm{I}=42.6$ min; group II $=48.3 \mathrm{~min}$; group III $=51.0 \mathrm{~min}$ ) when assayed by the one-stage clotting method as compared with the chromogenic method values (group $I=35.5 \mathrm{~min}$; group $\mathrm{II}=35.5 \mathrm{~min}$; group III $=41.6 \mathrm{~min}$ ). However, the adult values were nearly identical with both methods. It is possible that small amounts of circulating fibrin(ogen) degradation products prolonged the clotting time (8) and yielded an evelated heparin level when compared with the chromogenic assay.

The results of this study indicate that the greater $V_{d}$ of heparin in the newborn necessitates relatively larger loading doses of heparin per $\mathrm{kg}$ body weight to achieve the same plasma concentration when compared with the older children and adults. The higher clearance rates of the newborn infants should require larger maintenance rates to maintain a given heparin level. Preliminary studies of continuous infusions with therapeutic heparinization are ongoing and are supportive of this speculation. In extremely preterm infants of 25 to $28 \mathrm{wk}$ gestation, heparin clearance was less rapid with greater variation among babies.

AT-III is required for the function of heparin but in at least one patient with congenital AT-III deficiency reported by Marciniak et al. (15), circulating heparin levels achieved after a bolus injection were measured to be greater than predicted, suggesting that low levels of AT-III per se do not accelerate plasma heparin disappearance. In the same study adults with AT-III deficiency required larger heparin doses to prolong the thrombin time and the activated partial thromboplastin time. Previous studies $(2,3$, $22,24)$ have shown that newborns (term and preterm) have low levels of AT-III. The infants in this study showed a mean AT-III level of $25.5 \%$ of normal adult. Therefore, it is not surprising that these infants should require larger doses of heparin for an anti- 
Table 3. Antithrombin III-antigen levels in the study subjects

\begin{tabular}{lcc}
\hline & $\begin{array}{c}\text { Preheparin } \\
\text { (\% normal adult) }\end{array}$ & $\begin{array}{c}\text { 90 min } \\
\text { postheparin } \\
\text { (\% normal adult) }\end{array}$ \\
\hline $\begin{array}{l}\text { Adult subjects } \\
\overline{\mathrm{x}}\end{array}$ & 102.0 & \\
S.D. & 9.4 & \\
Infants & & \\
Overall & & 28.0 \\
$\overline{\mathrm{x}}$ & 25.5 & 5.0 \\
S.D. & 6.6 & \\
Group I & & 30.2 \\
$\overline{\mathrm{x}}$ & & 5.9 \\
S.D. & 29.1 & \\
Group II & 3.5 & \\
$\overline{\mathrm{x}}$ & & 29.0 \\
S.D. & & 3.2 \\
Group III & 26.4 & \\
$\overline{\mathrm{x}}$ & 4.0 & \\
S.D. & & 5.0 \\
\hline
\end{tabular}

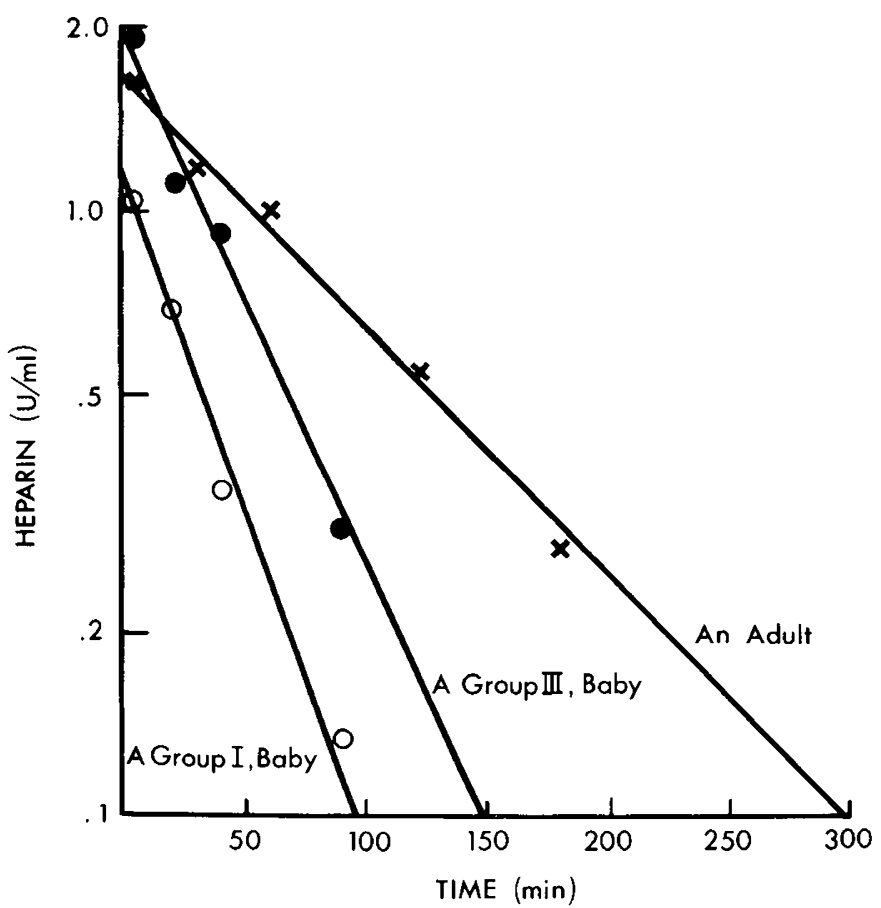

Fig. 2. Plasma heparin clearance in a representative group I baby, a group III baby, and an adult as determined by the chromogenic heparin assay.

coagulant effect.

It has been stated (7) that heparin may decrease circulating levels of AT-III. No decrease in AT-III Ag was noted during this study.

\section{REFERENCES AND NOTES}

1. Ballard, J. L., Kazmaier, K., and Driver, M.: A simplified assessment of gestational age. Pediatr. Res., 11: 374 (1977).

2. Barnard, D. R., and Hathaway, W. E.: Neonatal thrombosis. Am. J. Pediatr Hematol. Oncol., l: 235 (1979).

3. Barnard, D. R., Simmons, M. A., and Hathaway, W. E.: Coagulation studies in extremely premature infants. Pediatr. Res., 13: 1330 (1979).

4. Bell, W. N., and Alton, H. G.: A brain extract as a substitute for platelet suspension in the thromboplastin generation test. Nature (Lond.), 174: 880 (1954).

5. Boyd, J. F.: Disseminated fibrin thromboembolism among neonates dying more than 48 hours after birth. J. Clin. Pathol., 22: 663 (1969).

6. Chen, A. L., Hershgold, E. J., and Wilson, D. E.: One-stage assay of heparin. J. Lab. Clin. Med., 85: 843 (1975).

7. Collen, D., Schetz, J., DeCock, F., Holmer, E., and Verstraete; M.: Metabolism of antithrombin III (heparin cofactor) in man: effects of venous thrombosis and of heparin administration. Eur. J. Clin. Invest., 7: 27 (1977).

8. Denson, K. W. E., and Bonnar, J.: The measurement of heparin: a method based on the potentiation of anti-factor Xa. Thrombos. Diaths. Haemorrh., 30: 471 (1973).

9. Estes, J. W.: The fate of heparin in the body. Curr. Ther. Res. Clin. Exp., 18: 45 (1975).

10. Grossman, B. J., Heyn, R. M., and Rozenfeld, I. H.: Coagulation studies in the newborn infant. Pediatrics, 9: 182 (1952)

11. Hellem, A. J.: The adhesiveness of human blood platelets in vitro. Scand. J. Clin. Lab. Invest. Suppl., 51: 19 (1960).

12. Kitterman, J. A., Phibbs, R. H., and Tooley, W. H.: Aortic blood pressure in normal newborn infants during the first 12 hours of life. Pediatrics, 44: 959 (1969).

13. Laurell, C. B.: Electroimmunoassay. Scand. J. Clin. Lab. Invest., 29: 21 (1972).

14. Loughnan, P. M., Sitar, D. S., Ogilvie, R. I., and Neims, A. H.: The twocompartment open-system kinetic model: a review of its clinical implications and applications. J. Pediatr., 88: 869 (1976).

15. Marciniak, E., Farley, C. H., and DeSimone, P. A.: Familial thrombosis due to antithrombin III deficiency. Blood, 43: 219 (1974).

16. Markarian, M., Lubchenco, L. O., Rosenblut, E., Fernandez, F., Lang, D., Jackson, J. J., Bannon, A. E., Lindley, A., Githens, J. H., and Martorell, R.: Hypercoagulability in premature infants with special reference to the respiratory distress syndrome and hemorrhage. Biol. Neonate, 17: 98 (1971).

17. McAvoy, T. J.: The biologic half-life of heparin. Clin. Pharmacol. Ther., 25: 372 (1979).

18. Mokrohisky, S. E., Levine, R. L., and Simmons, M. A.: The relationship of umbilical artery catheter position and use to complication rates. N. Engl. J. Med., 299: 561 (1978).

19. Oppenheimer, E. H., and Esterly, J. R.: Thrombosis in the newborn: comparison between infants of diabetic and nondiabetic mothers. J. Pediatr., 67: 549 (1965).

20. Plumer, L. B., Kaplan, G. W., and Mendoza, S. A.: Hypertension in infants-a complication of umbilical arterial catheterization. J. Pediatr., 89: 802 (1976).

21. Rogner, G.: Heparin level during anticoagulant therapy in mature and premature newborn infants. Kinderaerzt1. Prax., 44: 193 (1976).

22. Schettini, F., De Mattia, D., Montagna, O., and Altomare, M.: Sviluppo postnatale dell' antitrombina III, del plasminogeneo, e dell' $\alpha_{2}$-macroglobulina nell' uomo. Riv. Ital. Ped. (I.J.P.), 2: 315 (1976).

23. Simon, T. L., Hyers, T. M., Gaston, J. P., and Harker, L. A.: Heparin pharmacokinetics: increased requirements in pulmonary embolism. Br. J. Haematol., 39: 111 (1978).

24. Teger-Nilsson, A. C.: Antithrombin in infancy and childhood. Acta. Paediatr. Scand., 64: 624 (1975)

25. Teien, A. N., Lie, M., and Abildgaard, U.: Assay of heparin in plasma using a chromogenic substrate. Thromb. Res., 8: 413 (1976).

26. Tyson, J. E., de Sa, D. J., and Moore, S.: Thromboatheromatous complications of umbilical arterial catheterization in the newborn period. CP Study. Arch. Dis. Child., 51: 744 (1976)

27. Wesley, J. R., Keens, T. G., Miller, S. W., and Platzker, A. C. G.: Pulmonary embolism in the neonate: occurrence during the course of total parenteral nutrition. J. Pediatr., 93: 113 (1978).

28. Requests for reprints should be addressed to: William E. Hathaway, M.D., Professor of Pediatrics, Box C220, University of Colorado Health Sciences Center, 4200 East Ninth Avenue, Denver, Colorado 80262 (USA).

29. This research was supported in part by U.S.P.H.S. Grant R01 HL 20337 and by Grant (RR-69) from the General Clinical Research Centers Program of the Division of Research Resources, the National Institutes of Health, and U.S.P.H.S. Grant 1-P02-CA-12247-01A1-CAP, CA-15564-01, and AM 18617.

30. Received for publication August 13, 1980.

31. Accepted for publication November 5, 1980. 